\title{
Sustainable city planning: preserving historical objects
}

\author{
U. Ulbar, L. Cazacova \& A. Eldelhun \\ Department of Architecture and Interior Architecture, \\ European University of Lefke, North Cyprus
}

\begin{abstract}
The historical environment of old cities is what draws a defining line detaching the past and present; it is that bridge, which connects the history of city foundation with the present veracity. Preservation, and restoring centers of antique cities already is the foremost task of modern city planning. The laws have already been passed and implemented which control this process.

Right now is the time to pay attention to the non-monumental antique structures (NMAS) which are remote from the historical city center. They are the ones that are most vulnerable and are facing amendments. As a consequence of scientific-technological progress, with society developing at an increasing pace; cities evolve and grow fast, simultaneously with the changes within the functional structures of the separate micro districts. All these changes directly and inevitably affect the antique architectural structures.

It is the historical objects and complexes located on the outskirts of the centers of the historical cities that are now isolated, and surrounded by newfangled structures.

In many cities there are streets and micro districts which are no longer a single ensemble, as they were initially. Constructions abruptly differ from each other in styles and number of floors. This is the exact reason why preservation of a city's historical environment, and its cultural heritage, is one of the priorities of modern city planning.

The purpose of this article is to develop a strategy to:

- Assign a definition to structures not considered to be monuments of historical, archaeological, and artistic value, located on the outskirts of the city centers, as NMAS.
\end{abstract}


- Locate NMAS in the present urban structures, and classify them conspicuous for their historical, archaeological, artistic or cultural interest.

- Define their value.

- Identify methods of preservation of NMAS according to their value.

Keywords: non-monumental structures, protecting heritage, cultural values, historical environment, old city planning.

\section{Introduction}

The historical environment is the mirror of a city and a country as a whole, which reproduces the process of development of economy, politics, culture, history and architecture. Naturally, conservation of all the historical buildings is not always feasible; however the purpose of the present generation is to unite the powers in the areas of city planning, economy and politics to preserve the historical and cultural heritage of the cities and the nation as a whole, and to transfer it to the next generation almost entirely.

Preservation and restoring the centers of antique cities is already the foremost task of modern city planning in the area of the preservation of historical and cultural heritage, and the laws have already been passed and implemented which control this process [2].

Right now is the time to pay attention to the monuments of architecture, history and culture which are remote from the city center. They are the ones that are more vulnerable and facing amendments. All changes which originate from scientific-technological progress, economy and city development inevitably redesign the historical structures. It is the historical objects and complexes located on the outskirts of the centers of the historical cities that are now isolated and surrounded by new, often inappropriate, structures.

Considering the urban settlement in Cyprus - the third biggest island in the North-Eastern part of the Mediterranean Sea (Figure 1), situated at the crossroads of the East-West and North-South navigation routes, it has impacts of these interplaying factors, since the island was ruled by many different conquerors throughout the centuries. According to an interview with Mr. Azimli, the General Manager of the Antiques and Museum Office, there are no governmental programmes created for the protection of non-monumental antique structures (NMAS) [3].

The main initiative of this article is to determine a strategy for locating the constructions (which are not considered as the important monuments and are not being guarded by the government), grant them a definition, determine their value in regard to historical, archaeological, artistical, architectural or cultural interest, and suggest a strategy and methods for their preservation and so protection of the wholesome architectural-historical ensemble of the city.

\section{Defining NMAS}

As cities grow, their historic cores in time become surrounded by new formal and/or informal urban developments with different architectural and urban 
features. Older historic cities with unique identities as well as with a considerable urban and architectural value exist in various parts of the world. The urban fabric of these cities is composed of several fragments: a historic core, colonial quarters, and urban developments built in the postcolonial era presenting striking physical contrasts and separate economic/social environments which coexist without much integration [4]. These cities are an important part of the urban and cultural heritage and have to be appreciated and valued in order to be carried to the future generations as well-functioning modern cities.

The buildings that exist to the present day from ancient times, shaping the character of a street and the buildings that have lost their original features have a great importance in the rearrangement. The internal organization and physical layout of an urban settlement is determined by various factors, including environmental issues, social and cultural values and economic and political forces. The interplay of these factors creates a diversified array of urban settlements, many of which contain an historic core with a vast architectural and urban heritage.

A careful and detailed study of the evolution process of cities in North Cyprus helps note that many indeed valuable antique buildings, which are located on the outskirts of the historical city center are lost within the modern structures, looking completely inadequate, out of place and as if lost in time [5]. Some of them are not residential, and are not used by anyone since they are in desperate need of reconstruction. The findings of this research lead to the notion that it is time for progressive action and safeguarding.

We suggest the definition NMAS to be assigned to the buildings and complexes, which are not yet considered as monuments and are not protected by the law, but are of cultural, historical, archaeological and architectural value. Urgent steps are to be taken to locate, classify and define their value, following up with commencement of reconstruction and protecting processes [2].

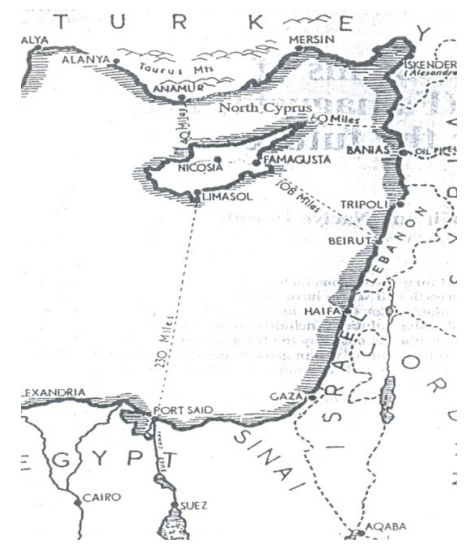

Figure 1: Location of Cyprus.

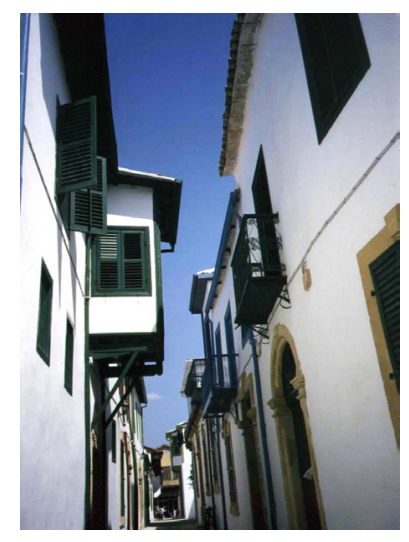

Figure 2: Old Street of Nicosia, Cyprus. 
NMAS are traced within the city by their physical and spiritual components, which define their character. The leading role in defining the criteria with the help of which the identification and selection of NMAS is to be performed, is executed by investigating the history of development of a city, micro district, street. Post detailed study and analysis of the history of development of cities in North Cyprus we determine specific parameters for identifying NMAS:

$\checkmark$ Primary: by the external features:

- Visual features of belonging to NMAS: the external outlook of the structure, style, proportions, dimensions, characteristics of constructions, building materials, the view of façade and internal spaces, ornamentations and different decorative elements that create its special character.

- Correlation of the "Structure" with the street or micro district in which it is located.

$\checkmark$ Secondary: coordination with historical archives of the city.

- Process of evolution of the street, city, region, location of the structure.

- Detailed study of historical and national status of the society that brought this "structure" to life.

- Initial purpose of this "structure".

Preservation of a city's historical style is the objective, which is under the competence of the administrative and city planning units of the city, meaning that by synchronizing the spheres of their operations: city planning - in locating NMAS and administration - in identifying normative regulatory base of city planning for safeguarding NMAS as heritage. Development of the strategy of preserving NMAS as the nation's heritage is being considered through the example taken: cities of North Cyprus.

\section{Locate NMAS in the present urban structures, and classify them conspicuous for their historical, archaeological, architectural and artistic or cultural interest}

A building or a group of buildings, micro districts, streets and wards are a historical document of urban life by reflecting a historical event, its relationship with the person or by reflecting a certain historical period [2]. The constructions or places that carry the footprints of the social development and reflect the composition of a society or its way of life should be protected. The immovable cultural works can be classified into two categories:

- The buildings that are in groups: the monumental buildings that have to be protected for the historical memories, for their features of having an architectural or aesthetic value of universal, national or regional level. The archaic constructions, the constructions of the middle ages, the religious and military examples of architecture, water constructions and palaces constitute the group that should be protected with their planning, structure, decoration and equipment.

- The Group Buildings: the housing (storage building) buildings that constitute the urban environment, that provide the region with a 
characteristic and that are built in the traditional building techniques are included within this group. The buildings that are going to be used with other aims facing minor amendments inside are also included within this concept.

A solution for the task of locating the potential NMAS and their identification lies in the in the competency of the city planning and municipal authorities. From the interview with Mr. Azimli, the General Manager of Antiques and Museum Office: voluntary organizations and students of architectural faculties help his department in compiling the lists of antique structures [3]. It would only be commonsensical to create a new additional body, which would merge history with architecture, archaeology and culture while identifying NMAS in a city. Let us conditionally name this body the Department of Location and Identification of Heritage to be Preserved (DLIHP).

The duty of DLIHP is to design a detailed plan for identifying, and designing a directory of NMAS according to their values for the future reconstruction and conservation. At this primary stage of location NMAS volunteers, represented by the students of architectural departments of Cyprus universities can be involved, especially since they're already taking part in the process according to Mr. Azimli, the General Manager of the Antiques and Museum Office [3]. The product of DLIHP's work should be as stated in Table 1.

Table 1: Preliminary list of potential NMAS.

\begin{tabular}{|c|c|c|}
\hline $\begin{array}{c}\text { Assigned } \\
\text { № }\end{array}$ & $\begin{array}{c}\text { Name of the NMAS and } \\
\text { details }\end{array}$ & Assigned potential value \\
\hline & $\begin{array}{c}\text { The name assigned to the } \\
\text { structure, its description, and } \\
\text { its location within the city } \\
\text { (street/micro district). }\end{array}$ & $\begin{array}{c}\text { Historical/archaeological/ } \\
\text { Architectural-artistic/cultural }\end{array}$ \\
\hline
\end{tabular}

\section{Define NMAS value}

Based on research conveyed in sections 1 and 2 of this article and a crafted list of NMAS, commence a more detailed assessment, for the future determination of the unique values of NMAS and assigning a status of national wealth for protection as heritage. At this secondary phase, the role of DLIHP including competent experts is priceless. The logic behind the identifying and locating NMAS is in planning the prospect development of the city and its reconstruction, taking into consideration positioning of NMAS and their protection, allocating secured areas nearby NMAS, so that the surroundings are in balance with the NMAS and are preserved as a single ensemble.

According to the results presented in Table 1 NMAS are classified by their category of value. The opinions about past what period of time a construction can be named as a historical work of art, changes from a country to another [5]. When there is no conscious social liking about the beauty of the structure to be 
protected, it is possible to make this decision for the society by opinions of the art historiographers and aesthetical experts.

A building could be considered old if it is 30 years old or more, and has some historical, social, cultural, sentimental, connections with the local community. After filtering out the NMAS into their classifications, Table 2 is drawn, which includes NMAS of historical value (Figure 5).

Table 2: $\quad$ Historical value.

\begin{tabular}{|c|c|c|c|}
\hline Assigned № & $\begin{array}{c}\text { Name of the } \\
\text { NMAS and } \\
\text { details }\end{array}$ & Antiquity & Value \\
\hline $\begin{array}{c}\text { NMAS are } \\
\text { assigned } \\
\text { numbers which } \\
\text { represent their } \\
\text { importance, } \\
\text { and is later } \\
\begin{array}{c}\text { marked on the } \\
\text { general city } \\
\text { map. }\end{array}\end{array}$ & $\begin{array}{c}\text { The name } \\
\text { assigned to the } \\
\text { structure, its } \\
\text { description, and } \\
\text { its location } \\
\text { within the city } \\
\text { (street/micro } \\
\text { district). }\end{array}$ & $\begin{array}{c}\text { The age of } \\
\text { NMAS is } \\
\text { determined and } \\
\text { the economical, } \\
\text { social and } \\
\text { political reasons } \\
\text { for its emerging. }\end{array}$ & $\begin{array}{c}\text { Is defined in the process of } \\
\text { weighting the pros and } \\
\text { contras for protection of a } \\
\text { certain NMAS, by } \\
\text { identifying those values, } \\
\text { which would be lost in the } \\
\text { historical heritage of the } \\
\text { city with the loss of this } \\
\text { particular NMAS. }\end{array}$ \\
\hline
\end{tabular}

The archaeological heritage constitutes the basic record of past human activities. It is that part of the material heritage in respect of which archaeological methods provide primary information. It comprises all vestiges of human existence and consists of places relating to all manifestations of human activity, abandoned structures, and remains of all kinds (including subterranean and underwater sites), together with all the portable cultural material associated with them. After NMAS with potential archaeological value are classified Table 3 is drawn.

Buildings that have architectural and artistic value are the ones having distinctive features and details of the period in which they have been constructed. The fact that an old building is surrounded now by ugly new/modern buildings does not mean its architectural value has risen, comparative value-wise perhaps, but not in its absolute value.

Table 3: $\quad$ Archaeological value.

\begin{tabular}{|c|c|c|c|}
\hline Assigned No & $\begin{array}{c}\text { Name of the } \\
\text { NMAS and } \\
\text { details }\end{array}$ & Antiquity & $\begin{array}{c}\text { Archaeological } \\
\text { Value }\end{array}$ \\
\hline $\begin{array}{c}\text { NMAS are } \\
\text { assigned } \\
\text { numbers which } \\
\text { represent their } \\
\text { importance, and } \\
\text { is later marked } \\
\text { on the general } \\
\text { city map. }\end{array}$ & $\begin{array}{c}\text { The name assigned } \\
\text { to the structure, its } \\
\text { description, and its } \\
\text { location within the } \\
\text { city (street/micro } \\
\text { district). }\end{array}$ & $\begin{array}{c}\text { An approximate age } \\
\text { of NMAS is } \\
\text { determined, and its } \\
\text { reasons behind its } \\
\text { archaeological } \\
\text { explorations and their } \\
\text { expected results. }\end{array}$ & $\begin{array}{c}\text { In accordance to the } \\
\text { analysis of findings } \\
\text { from the previous } \\
\text { column, the value of } \\
\text { NMAS in the area } \\
\text { of archaeology is } \\
\text { determined. }\end{array}$ \\
\hline
\end{tabular}




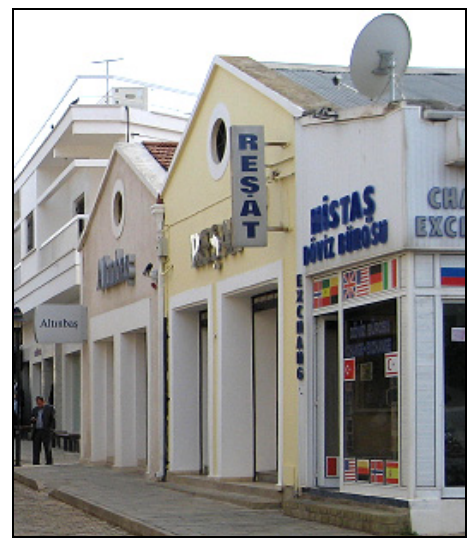

Figure 3: Storage buildings in the English period (Famagusta, Cyprus).

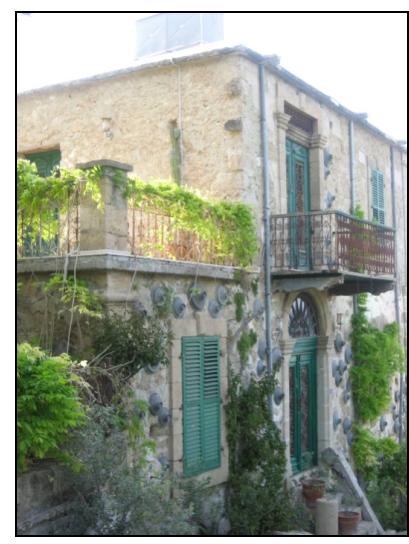

Figure 4: $\quad$ Estate agency office in Lapta, Cyprus.

Buildings that are tissue filler have reasonable proportions and measurements, reflecting the traditional patterns of an area. Buildings from specific periods also have some noteworthy features that are considered worthy of preservation.

Buildings of environmental value are those that do not have a very strong architectural character but have important proportions and functions in the pattern area. These are the storage buildings from British period having the same details, dimensions and forms in those areas in which they exist (Figure 4).

After filtering out NMAS which have a potential relation to Architectural value, Table 4 is formed.

Cultural heritage includes NMAS such as historic places, monuments, artifacts and intangible attributes of a group or society that are inherited from past generations, maintained in the present and bestowed for the benefit of future generations. These include objects significant to the archaeology, architecture, science or technology of a specific culture (Figure 2).

Table 4: $\quad$ Architectural value.

\begin{tabular}{|c|c|c|c|}
\hline Assigned № & $\begin{array}{c}\text { Name of the } \\
\text { NMAS and } \\
\text { details }\end{array}$ & Antiquity & Value \\
\hline $\begin{array}{c}\text { NMAS are } \\
\text { assigned } \\
\text { numbers which } \\
\text { represent their } \\
\begin{array}{c}\text { importance, and } \\
\text { is later marked } \\
\text { on the general } \\
\text { city map. }\end{array}\end{array}$ & $\begin{array}{c}\text { assigned to the } \\
\text { structure, its } \\
\text { description, and } \\
\text { its location } \\
\text { within the city } \\
\text { (street/micro } \\
\text { district). }\end{array}$ & $\begin{array}{c}\text { The age of } \\
\text { NMAS, the } \\
\text { materials used in } \\
\text { its construction } \\
\text { and décor, style, } \\
\text { and the conditions } \\
\text { causing its origin. }\end{array}$ & $\begin{array}{c}\text { In accordance to } \\
\text { findings in the previous } \\
\text { columns the value of a } \\
\text { particular NMAS as an } \\
\text { architectural heritage } \\
\text { and its role in the } \\
\text { process of evolution of } \\
\text { the city is determined }\end{array}$ \\
\hline
\end{tabular}


Cultural heritage influences people - individual, local and national identities. It shapes relationships with neighbors and with other communities around the world.

Cultural heritage promotes human understanding and economic development in an increasingly interdependent world. After selecting NMAS which have a potential cultural value, Table 5 is formed.

Table 5: $\quad$ Cultural value.

\begin{tabular}{|c|c|c|c|}
\hline Assigned No & $\begin{array}{c}\text { Name of the } \\
\text { NMAS and } \\
\text { details }\end{array}$ & Antiquity & Value \\
\hline $\begin{array}{c}\text { NMAS are } \\
\text { which represent } \\
\text { their importance, } \\
\text { and is later marked } \\
\text { on the general city } \\
\text { map. }\end{array}$ & $\begin{array}{c}\text { The name } \\
\text { assigned to the } \\
\text { structure, its } \\
\text { description, and } \\
\text { its location } \\
\text { within the city } \\
\text { (street/micro } \\
\text { district). }\end{array}$ & $\begin{array}{c}\text { The age of NMAS, } \\
\text { civilization and } \\
\text { culture of the society } \\
\text { which caused its } \\
\text { origin are determined } \\
\text { (by who, for } \\
\text { what/who/which } \\
\text { purpose was it built) }\end{array}$ & $\begin{array}{c}\text { The value of a } \\
\text { certain NMAS for } \\
\text { preserving the } \\
\text { culture of the cities } \\
\text { nation, the } \\
\text { influence of this } \\
\text { NMAS on the } \\
\text { process of evolution } \\
\text { of the society. }\end{array}$ \\
\hline
\end{tabular}

Using the outcome of the above investigations, their systematization and summarizing tables № 1,2,3,4 and 5, a final spreadsheet (Table 6) is generated in which each NMAS has its own assigned № (by which this NMAS is represented on the city map), by this number the value of this NMAS is determined and the order of the reconstructive and protective projects is assembled for financing and capital investments. The value that historical building has or its degree of being a monument are discussed and agreed on by experts of DLIHP.

Table 6: Final spreadsheet which represents the value of NMAS in accordance to the assigned №.

\begin{tabular}{|c|c|c|}
\hline № & $\begin{array}{c}\text { Name of the NMAS and } \\
\text { details }\end{array}$ & Value \\
\hline $\begin{array}{c}\text { The final number } \\
\text { assigned to } \\
\begin{array}{c}\text { NMAS, which } \\
\text { represents its } \\
\text { value. }\end{array}\end{array}$ & $\begin{array}{c}\text { The name assigned to the } \\
\text { structure, its description, and } \\
\text { its location within the city } \\
\text { (street/micro district). }\end{array}$ & $\begin{array}{c}\text { Category of value to which this } \\
\text { NMAS belongs } \\
\text { Historical/archaeological/ } \\
\text { architectural-artistic/cultural }\end{array}$ \\
\hline
\end{tabular}

Evidently, exact boundaries do not exist as to which type of values does a certain structure belong, or the margin is distorted. This calls for the unification of powers of the administrative bodies to unmistakably affirm inclusion of each existing structure within the city into NMAS. It's not as crucial into which category of group of values would NMAS be placed into, as the fact of recognition of the structures as NMAS and the need of their preservation. 


\section{Identify methods of preservation of NMAS according to their value}

At present, approved measures in the protection of heritage are still in the transition stage and do not comprise the laws of protecting NMAS [6]. The city planning system is not yet fully formed; however it already does not comply with modern standards. Development of progress of society is often a few steps ahead of the advancement of laws [3]. There is a need for urgent, drastic action, which would surpass and regulate the development of the city, persuading the protection of NMAS, the heritage of the city, and its environment:

- Recommend the transfer of the role of NMAS and the territory on which it is located from secondary into primary role of city planning, with an aim of protecting the NMAS itself and the initial environment of the city.

- Analyze and systematize already existing regulations in the spheres of city planning and heritage protection.

- Generate recommendations/methods for implementing those regulations in the contemporary standards of economics, city and society development.

New socio-economical conditions of the country are reflected on the city planning and protection of heritage and lead to existing consequences in this sphere. Interest in usage of the properties increases, and as a result the problem of preserving the genuine historical values of NMAS becomes more evident. Since the vast majority of NMAS are located in the old city structure, not on the outskirts, the interest in them is quite comprehendible. However, the owners or users of NMAS frequently do not understand their authentic meaning, value and therefore change the structure according to its new purpose and the owners'/users' needs. In this way, NMAS changes its appearance, the conditions of its comprehension, the wholesomeness of the environment, style and therefore its value.

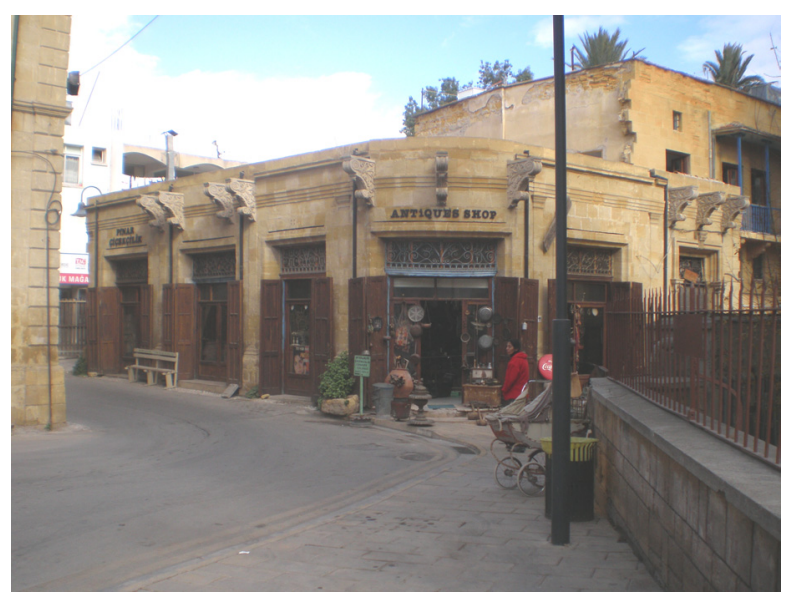

Figure 5: Antiques shop in Nicosia, Cyprus. 
Based on the analysis of the presently existing methods of regulating city planning, we suggest taking a look at the problem of preserving heritage from a fresh angle [7]. Time has come for transit to individual, regional planning, according to the systematizing and considering the territories where NMAS are located.

Conservation, diminishing governmental financing protection of heritage, forming alternative sources of financing, privatization of NMAS - are just some of the methods which would definitely lead to significant positive changes in the perspective of heritage protection.

Conservation is a non negotiable effective method of protection, however regarding NMAS, not effective enough. This way requires major governmental financing, which is quite problematic in the current economical and political conditions.

Explorations and analysis in spheres of reconstruction and restoration in various countries show that these techniques are less attractive to investors than a newly projected structure, despite the beneficial location. There should be new methods of stimulating the attractiveness of investment in NMAS, which could be implemented by subsidizing, stimulating and localizing exceptional legal conditions.

A relatively effective method of protecting NMAS is subsidizing compensating the expenditure accrued while supporting the structures in the condition which they require. Subsidizing could be materialized with the help of governmental and non-governmental organizations (such as charitable and social funds, which raise capital) or their partial participation: optimizing legislation in sphere of subsidizing, basing on the results of Table 6 of this article (the list of NMAS and their assigned numbers), and evaluating the order of subsidiaries for their restoration.

In accordance with investigations into the experiences of various countries in the sphere of protecting heritage, it is seen that the successful paths were taken with the help of stimulus packages (which often already act in the country in the sphere of protecting monuments) [8]. The Stimulation Method - decreasing taxation upon the investments for reconstruction works, diminishing the rent rates, providing privilege credit terms to the tenants, freedom from some tariffs, legal delay of tax payments, tax deductions - with the same success it is applicable in the sphere of protecting NMAS. Optimizing legislation in sphere of stimulation - the next effective method in regards to protecting NMAS.

The education of a new generation and rising awareness within the society plays one of the roles of primary significance in protecting non monetary wealth of nation [3]. It very often happens so that the society, due to unawareness does not realise the real value of historical environment that surrounds them. In order to reduce those occurrences, the Ministry of National Education could introduce a subject called "Heritage" into school programmes, so that children start learning about the objects of their countries heritage, which in its turn will help them understand the authentic value of heritage and learn to protect it from young age. 


\section{Conclusion}

Regardless of the country in which the old historical cities exist, with their unique architecture they reflect the specifics of the culture, nation and history which identifies those cities, reveals the distinction of one city from the other, and by that differentiating between the cultures of the countries and nations.

Conservation and revitalization of the historic urban quarters should be considered in a mutually exclusive fashion. Additionally, it should be noted that area-based preservation involves many owners, users, institutions, in another words many actors and is influenced by various laws and regulations. Every society must strike a balance between the rights of these actors to pursue their interests and aspirations, and the public interest in heritage conservation. Successive preservation and revitalization of NMAS is a matter of good management. It is important to take pains over the monuments that carry an importance for human history as they are the concept of the world's architecture.

In the process of inspecting the existing regulations regarding protection of heritage, drawbacks in the sphere of protection of historical structures in North Cyprus were determined, [6] the most vivid examples of which are: NMAS are not protected by the law, no administrative body is involved in account and solution of problems of NMAS, and there is a lack of investments that support protected heritage. Below are the suggestions which are based on the strategy developed within the article that will help decrease/obliterate the drawbacks:

- Definition of NMAS is blueprinted,

- Strategy of identifying and classifying NMAS by their value and type of heritage it represents is developed,

- Administrative and monetary methods of protecting NMAS are suggested,

- Recommendations are given in favor of foundation of a new administrative department - DLIHP (Department of Location and Identification of Heritage to be Preserved) and its duties were defined as follows: to be responsible for detecting and systematizing NMAS by their values, prioritize NMAS which are to receive investments for restoration and control protective city planning.

- The role of education of new generation in the field of protecting heritage is highlighted.

One of the main problems regarding the protection of heritage in Cyprus today is: what to protect? This problem exists not only in Cyprus, but also in many other developing countries. We, as the world's citizens, do not have the right to postpone the solution of this problem to the future years for the generations to come.

\section{References}

[1] Famagusta Improvement, C. F. Roworth Limited, 54, Grafton Wav. London, W.I. (Appointed by the Government of Cyprus the Government 
Printers of this Edition, of Laws within the meaning of the Evidence (Colonial Statutes) Act, 1907) 1959 edition, Chapters 56, 96, 337, Cyprus.

[2] Oktay, B., "A model for measuring the level of sustainability of historic urban patterns: comparative case study of Kyrenia and Famagusta in north Cyprus", 2005

[3] Ulbar, U., "Interview with Mr. Fuat Azimli, General Manager of Antiques and Museum Office", Antiques and Museum Office, Nicosia, Cyprus, 04/05/2009

[4] Ulbar, U., "Image Analysis of Istiklal Street in Famagusta", Master Thesis, European University of Lefke, Department of Architecture, Lefke, North Cyprus, pages 21-26, 44-48, 61-64, 2008

[5] Delaval, C.C., "Excerpta Cypria", Materials for a History of Cyprus, Nicosia, Cyprus, 1969

[6] "Law of the Antiques and Historical Heritage and its Contents", number 60/1994, Nicosia, CYPRUS

[7] Naciye, D. 'A Model for conversation and revitalization of Historic Urban Quarters in Northern Cyprus', 2000

[8] www.architexturez.net/+/subject-listing/000065.shtml

[9] www.international.icomos.org/publications/wash121.pdf

[10] acts.oireachtas.ie/en.act.1999.0019.1.html

[11] www.international.icomos.org/risk/2001/icahm2001.htm

[12] www.unescobkk.org/index.php?id=555

[13] www.nypl.org/press/2007/FacadeRestor.cfm 